\title{
Participatory Demonstration and Evaluation of 'Chefeka' Hive Technology in Abaya and Yabello Districts of West Guji and Borana Zones of Oromia Regional State, Ethiopia
}

\author{
Ahmed Mohammed Abdulla* Feyissa Desiso Ibsa Aliyi \\ Oromia Agricultural Research Institute, Yabello Pastoral and Dryland Agriculture Research Center, \\ P.O.Box. 85, Yabello, Ethiopia
}

\begin{abstract}
The active role of pastoralists in developing beekeeping technologies has been largely underestimated and underutilized. In view of this the study was conducted during the 2013/14 and 2014/15 at Abaya and Yabello Districts of West Guji and Borana Zones to evaluate the productivity and profitability of Chefeka hive made from locally available materials under pastoralists' and farmers' circumstances, to create awareness on Chefeka hive made from locally available materials for pastoralist beekeepers, and to improve farmers' and patoralists' knowledge and skill of application/use of the Chefeka hive technology. Generally one demonstration site have been selected from each districts based on the potentiality of the area and participation of pastoralists in beekeeping activities. For evaluation and demonstration of the technology various participatory approaches were employed namely, Pastoralists Research Groups Formation, Training, Client-oriented research approach workshop and exchange visit. At each site three chefeka hives have been constructed and yield comparison was made with traditional beehives and analyzed using descriptive statistics. The result of the demonstration showed that the honey bees have accepted the chefeka hive made from locally available materials. The average honey yield obtained per annum from chefeka hive made from locally available materials and traditional hive is $11 \mathrm{~kg}$ and $3 \mathrm{~kg}$, respectively. Even though chefeka hives' cost of production is different from place to place, it is on average 62.00Birr. At all demonstration sites, the beekeepers have confirmed as the technology fits to their socio-economic situation(affordable \& manageble). Hence, the technology is productive, affordable and strongly recommended to be more popularized for maximizing honey production and alleviating the existing problems of traditional beehives.
\end{abstract}

Keywords: Chefeka hive, Participatory demonstration, Beekeeping

DOI: $10.7176 / \mathrm{JBAH} / 10-18-03$

Publication date:September $30^{\text {th }} 2020$

\section{Introduction}

It is vital to note that no amount of research will lead to sustainable agricultural development if the countries in Africa do not address the constraints to sustainable agriculture (Chambers et al,1989).

Most importantly, they have to use an extension strategy that allows the stakeholder to be part of the research agenda. When the stakeholders to agricultural research are part of the planning and implementation, they have the sense of belonging and ownership.

The use of Pastoral/Agro-pastoral Research Groups (PAPRG) is one of the approaches, which make the pastoralist/agro-pastoralist to be central to agricultural research and dissemination: to ensure synergies from complementary investments in research and extension resulting in more effective and efficient systems participatory technology beekeeping generation and transfer play great role in changing the livelihood of pastoralist/agro-pastoralist beekeepers.

In view of this an attempt was made to make participatory promotion of Chefeka hive. Particularly, it helps beekeepers who have economic limitation for using other types of hives. As study report of Nuru and Eddesa (2005) it is possible to use hand-made Chefeka hives and frames from locally available materials.

Different beekeeping technologies were adapted by the Pastoral and Dry-land Agriculture Research Center in addressing the technology gap that improves traditional beekeeping practices for improving the livelihood of pastoralists/agro-pastoralists.. Nevertheless, those technologies were not sufficiently introduced to all potential production sites. Recently adapted beekeeping technology (Chefeka hive) was also found potential for small scale pastoralist/farmers. The technology was good yielder compared to traditional ones and it poses an opportunity for the farmers and pastoralists who cannot afford for modern beekeeping technologies especially in Borana lowlands where moisture is a limiting factor for crop production. On the other side, most of the farming community had little chance to know and make own choice from the ranges of available improved beekeeping technologies.

Therefore, this activity was designed to demonstrate and evaluate the improved beekeeping technologies to farmers and pastoralists in potential honey producing areas in the West Guji and Borana Zones. 


\section{Methodology}

2.1 Description of the study area

Yabello is found in southern Ethiopian rift valley $575 \mathrm{~km}$ away from Addis Ababa. It has an altitude of 1656masl. The area is characterized by erratic, low and unpredictable seasonal rain fall. Occasionally high temperature during the rainy season exacerbates soil moisture stress. As a result moisture deficit is the most pressing problem causing frequent crop failure in the area. Annual rain fall ranges from $500 \mathrm{~mm}$ to $700 \mathrm{~mm}$. Main season rain fall starts in March and reaches its peak in April. Soil in this area is of diverse type, generally low in organic matter, poor in water holding capacity and Electrical conductivity hence drought prone contributing to periodic crop moisture deficit (Habtu, 1995). Abeya (Bunata) is also found in southern Ethiopian rift valley $367 \mathrm{~km}$ away from Addis Ababa. It has an altitude of 1641 masl, annual rain fall ranging from $900 \mathrm{~mm}$ to $1400 \mathrm{~mm}$ and temperature $16-28^{\circ} \mathrm{c}$ ). It is characterized by black paddy clay soil.

\subsection{Site and farmers' selection}

The activity was carried out for two years ( 2013/14-2014/15) in two Districts (Abaya and Yabello) of West Guji and Borana Zones of Oromia Region purposively selected based on potential of the area and participation of farmers/pastoralists in beekeeping activities.

There were 20 and 15 participating farmers/pastoralists in Abaya and Yabello, respectively based on their interest towards the technologies, willingness to manage the research activity. Majority of the farmers/pastoralists were male. The number of female farmers/pastoralists ranged from 2 in Abaya to 4 in Yabello. The District agricultural/patoral office experts and Development Agents (DA) had also taken part in the implementation process.

Multidisciplinary team composed of an Agriculutural Extensionist, livestock breeder, bee expert, and entomologist were in charge of this activity.

\subsection{Research design}

At each site three Chefeka hives were constructed from the locally available materials and installed side by side with the traditional hives. For comparison purpose, honey yield data of both Chefeka and traditional hives at respective demonstration sites were collected. The cost of Chefeka hive construction was also estimated at each demonstration sites.

\subsection{Technology evaluation and demonstration methods}

The evaluation and demonstration of the trial was implemented on farmers/pastoralists' fields to create awareness about the beekeeping technology. The evaluation and demonstration of the trials was followed process demonstration approach by involving F/PRGs, development agents and experts at different stage of the research work. The activity was jointly monitored by F/PRGs, researchers, experts and development agents.

\subsection{Data collection}

During the study, the data were collected on Chefeka hive acceptance by honeybees, honey yield of two seasons, attitudes of farmers/pastoralists towards Chefeka hives and costs of Chefeka production. For gathering information observation, structured interview schedule, key informant interview and group discussion were used.

\subsection{Data analysis}

The collected data (quantitative data) were analyzed by using descriptive statistics such as average and frequency distribution while qualitative data were analyzed using preference ranking.

\section{Results and Discussion}

\subsection{Training of farmers and other stakeholders}

Trainings were given in 2013/14 and 2014/15 (Table 1). This includes both theoretical and practical types of training. The following table illustrates the number of farmers/pastoralists, DAs annd experts participated on the training.

Table 1: Training of farmers/pastoralists and other stakeholders

\begin{tabular}{lllllll}
\hline \multirow{2}{*}{ Year } & \multicolumn{5}{c}{ Participants } \\
\cline { 2 - 7 } & \multicolumn{2}{l}{ Experts (DA + SMS) } & \multicolumn{5}{l}{ Farmers/pastoralists } \\
\cline { 2 - 7 } & Male & Female & Total & Male & Female & Total \\
\hline $2013 / 14$ & 6 & 5 & 11 & 29 & 6 & 35 \\
$2014 / 15$ & 5 & 4 & 9 & 29 & 6 & 35 \\
\hline
\end{tabular}

The contents of the training were: the advantage and disadvantages of traditional, transitional and improved beekeeping, colony organization, honey plant and site selection, honey bee diseases, enemy control and honey bee poising seasonal colony management, hive product handling, processing and marketing, design and 
construction of Chefeka hives. At phase two, more of practical training was given at each host beekeepers' apiary site. It consists of construction of Chefeka hive from locally available materials, methods of transferring honeybee colonies from traditional hive to Chefeka hives. Phase three of the training was focused on methods of inspection, feeding, harvesting, processing of honey and beeswax.

\subsection{Farmers/pastoralists' and other stakeholders' participation in demonstration}

Identification and documentation of major stakeholders in beekeeping technology promotion in the two Districts, and formation of multidisciplinary team from Yabello Pastoral and Dryland Agriculture Research Center and from both Districts were conducted during the initial stage of the research activity.

The team consists of Agricultural Extension, Appiculture research teams of YPDARC and beekeepers of potential Districts, District Bee Experts, District Extension team leader, and Development Agents (DAs) from the respective Districts.

Based on a pre-informed visit it was attempted to follow up the trial on average every two weeks. During each visit discussions were made with the farmers/pastoralists DAs and experts right on the apiary sites in order to jointly evaluate the performance of the hives on the field. During the visit both farmer/pastoralis' and DAs' data recording format were checked to observe how they handled the information gathering process.

\subsection{Yield performance and economic analysis}

In all demonstration sites, the honeybees accepted the Chefeka hive made from locally available materials. The comparison of honey yield of Chefeka hive with traditional hive was also done at each demonstration sites. Accordingly, the average yield obtained per annual from Chefeka hive made from locally available materials and traditional hive was $11 \mathrm{~kg}$ and $3 \mathrm{~kg}$, respectively. The price of one $\mathrm{kg}$ crude honey on average was 46.25 . Even though chefeka hives' cost of production is different from place to place, it was on average 62.00 Birr. It is too cheap when compared to machine made top bar hives which was estimated to be 400.00 Birr.

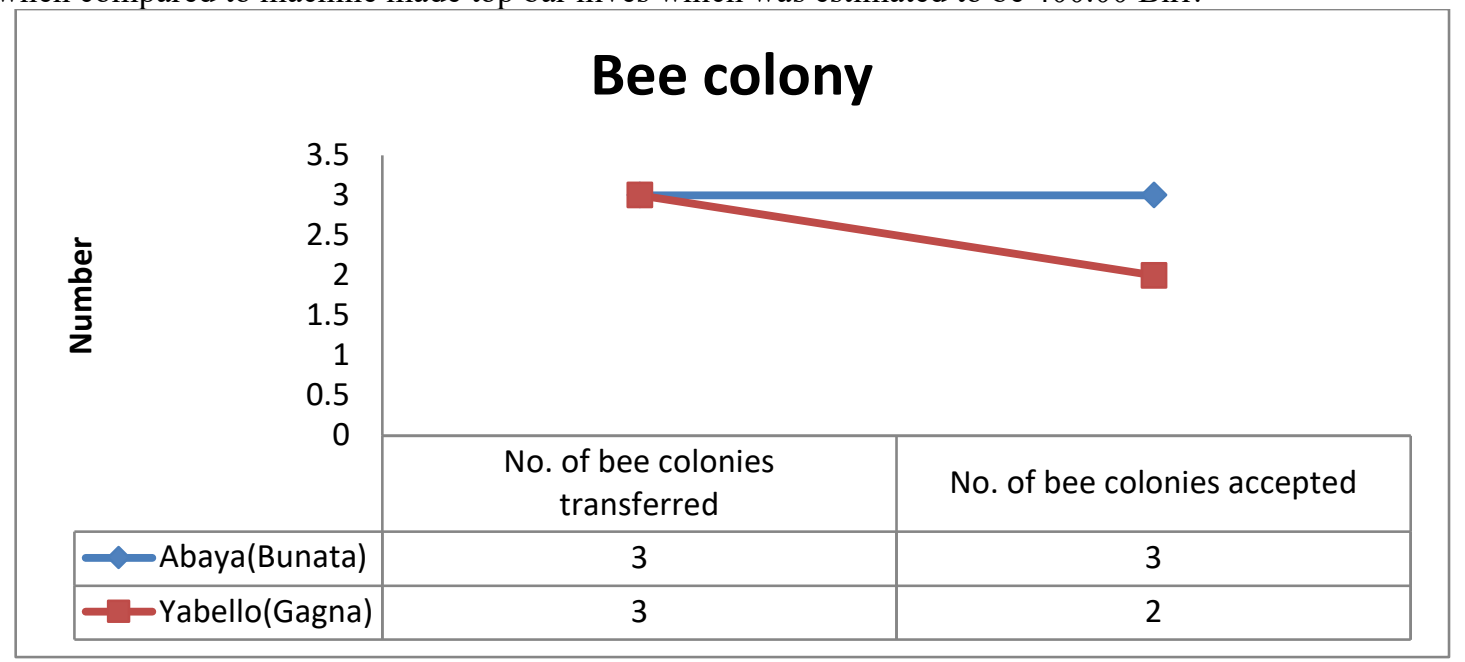

Figure 1: Acceptance of Chefeka hives by honeybees at different demonstration sites 


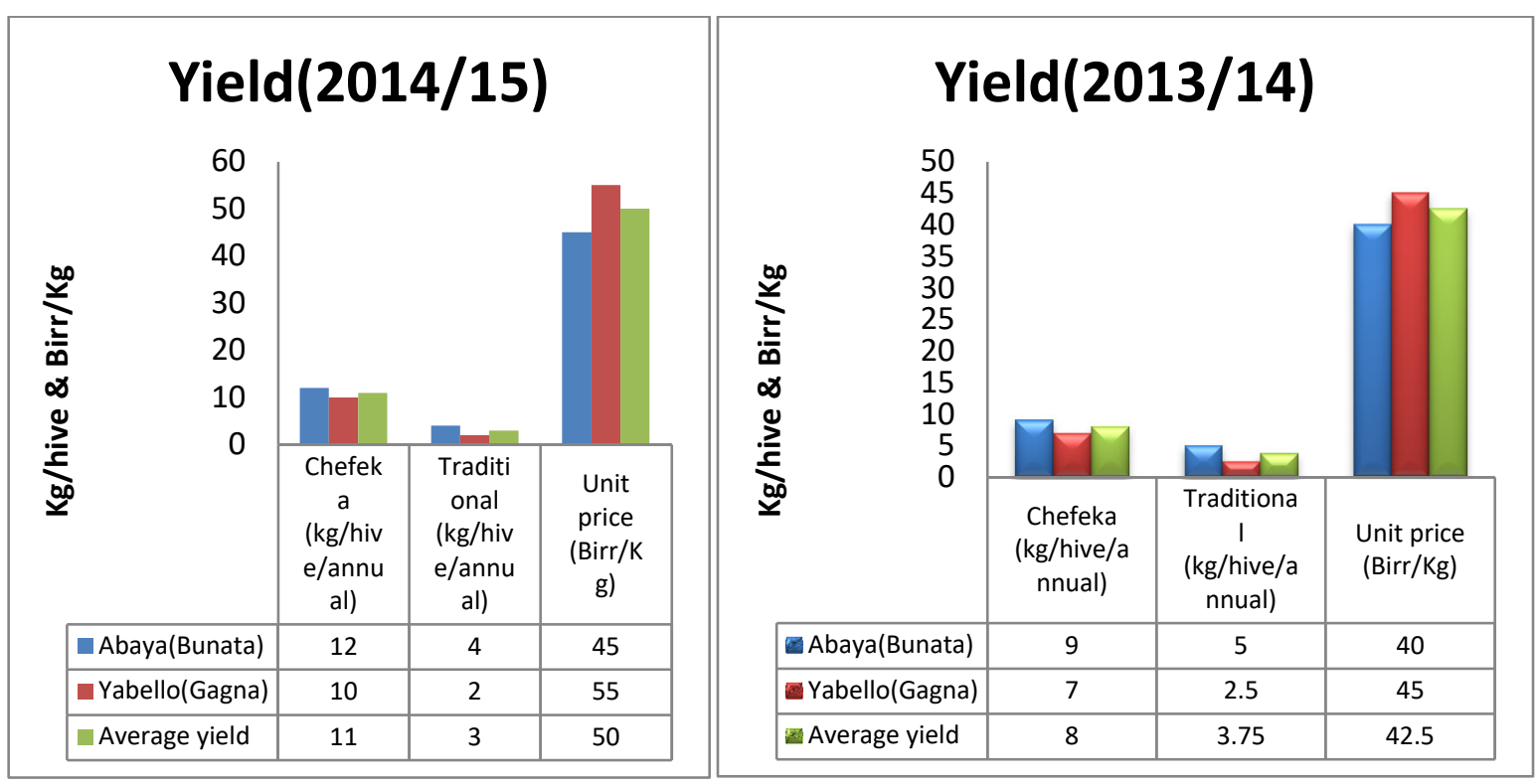

Figure 2. Annual crude honey yield of Chefeka and Traditional hives, and Price of the yield

Average cost of hives as estimated at respective demonstration sites/Districts were 65 and 15 for Chefeka and Traditional, respectively as illustrated in the next table. This variation was due to availability of locally available materials.

Table 2. Cost of hives as estimated at respective demonstration sites

\begin{tabular}{llll}
\hline \multirow{2}{*}{ No. } & District & \multicolumn{2}{c}{ Types of hives } \\
\cline { 3 - 4 } & & Chefeka & Traditional hive \\
\hline 1 & Abaya & 56 & 10 \\
2 & Yabello & 68 & 20 \\
Average & & 62 & 15 \\
\hline
\end{tabular}

\subsection{Farmers/pastoralists' opinion/perception}

On the exchange visit demonstration site of Abaya district namely: Bunata was visited. The participants were exchanged their views, opinions and shared their experience. Above all, it created an opportunity for popularization of the technology. In the same token, on the client-oriented research workshop key problems to beekeeping sector were identified and thorough discussion was made to alleviate the existing problems. It also created a good opportunity for researchers to conduct demand driven beekeeping technology generation and for Pastoral and Rural Development Offices gave lessons on which beekeeping technology popularization work to be done.

An assessment on attitude of beekeepers towards the technology was also made; accordingly, in all demonstration sites the beekeepers suggested that the technology is appropriate, productive, and cost effective.

\section{Conclusion and Recommendation}

\subsection{Conclusion}

Recently, there has been growing dissatisfaction with the poor rates of adoption of beekeeping technologies, particularly for resource poor farmers/pastoralists. This poor adoption has resulted partly because beekeeping technologies are developed with little input from farmers/pastoralists and other stakeholders.

Cognizant of this fact, YPDARC has tried to adopt various participatory research approaches to improve farmers/pastoralists' involvement in beekeeping technology generation and promotion. Although, it may be too early to talk about the impact of participatory beekeeping technology promotion within this short time, from Chefeka hives with its improved management intervention one can see indications of positive impact of the approaches in terms of providing good lessons for researchers, extension workers and farmers/pastoralists in the study areas.

\subsection{Recommendation}

The technology is feasible and strongly recommended to be popularized for maximizing honey production and alleviating the existing problems of traditional beehives. Hence, the Regional Pastoral and Agricultural Development Offices, NGOs and other concerned bodies may include the technology in their agricultural development program.

For effective utilization of the technology, short-term beekeeping training is required. Yabello Pastoral and 
Dryland Agriculture Research Center may also include the technology in its on spot and on station beekeeping training program.

\section{References}

Chamers R,P. Arnold, T.Lorri Ann (Eds). 1989. Farmer first: Farmer innovation and agricultural research. London, Intermediate Technology Publications.

Habtu, A., 1995. Proceedings of the 25th Anniversary of Nazret Agricultural Reseach Center: 25 years of experience in lowlands crops research, 20-23 September 1995. Nazret, Ethiopia.

Nuru Adigaba and Eddesa Negera 2005. Study on making Top-Bar Hive and frame cheap and locally available materials. In : Proceeding of conference of 4th Ethiopiaan Beekeepers Association, April 2005, pp.1-8. Addis Ababa. 